\title{
IS IT TRUE THAT LOMBOK DESERVES TO BE A HALAL TOURIST DESTINATION IN THE WORLD? A PERCEPTION OF DOMESTIC TOURISTS
}

\author{
Rahmawati RAHMAWATI \\ Mulawarman University, Faculty of Economics and Business, Department of Management, Samarinda City, Indonesia, e-mail: Rahmawati@ feb.unmul.ac.id. \\ Kiki OKTORA* \\ Universitas Pakuan, Faculty of Economics, Department of Management, Bogor City, Indonesia, e-mail: kiki.oktora@unpak.ac.id.
}

Sri Langgeng RATNASARI

University of Riau Kepulauan, Faculty of Economics, Graduate Program, Batam City, Indonesia, e-mail: sarisucahyo@yahoo.com.

Ramadania RAMADANIA

Tanjungpura University, Faculty of Economics and Business, Pontianak City, Indonesia, e-mail: ramadhania@ekonomi.untan.ac.id.

Dio Caisar DARMA

Department of Management, Samarinda High College of Economics, Samarinda City, Indonesia, e-mail: diocaisar@ stiesam.ac.id.

Citation: Rahmawati, R., Oktora, K., Ratnasari, S.L., Ramadania, R., \& Darma, C.D. (2021). IS IT TRUE THAT LOMBOK DESERVES TO BE A HALAL TOURIST DESTINATION IN THE WORLD? A PERCEPTION OF DOMESTIC TOURISTS. GeoJournal of Tourism and Geosites, 34(1), 94-101. https://doi.org/10.30892/gtg.34113-624

\begin{abstract}
Lombok is a tourist destination that presents interesting diversity for tourists. During its development, Lombok has applied the concept of halal tourism which includes services, serving halal food, spiritual needs, communication, and other matters related to halal branding. This study focuses on informants' perceptions of the relationship between tourism index, experience quality, and revisit intention of tourist destinations in Lombok. The study was conducted by surveying 87 tourists who came from Indonesia, specifically Muslims, those who have stayed in Lombok and have visited at least in the last 24 months. The most suitable informant unit in the sample is purposive. We use the PLS analysis model to simplify data processing. The findings of the study are divided into 3 hypotheses which explain that the season index has a significant effect on experience quality. Furthermore, experience quality has a significant effect on revisit intention, and the tourism index has no significant effect on revisit intention. The novelty of this study lies in the uniqueness of the object, analysis model, and variables that have been designed so that it is very interesting in its presentation and is a distinct difference from other studies.
\end{abstract}

Key words: tourism index, experience quality, revisit intention, halal tourism, Lombok

\section{INTRODUCTION}

Islam is considered to be the fastest-growing religion in the world. At least $10 \%$ of Europeans are expected to embrace this religion by 2050. Islam is predicted to become the largest religion in the world at the end of the $21^{\text {st }}$ century. Seeing the rapid growth of Islam, tourism is a good opportunity to be caught and worked on, so that at this time many countries are developing tourist areas with the concept of halal tourism. Because there are several rules in Islam that must be carried out by its adherents, a concept of halal tourism that is friendly to Muslims is needed (Satriana and Satriana, 2018; Battour and Ismail, 2016; Suradin, 2018). Halal tourism can be defined as a tourism concept designed to make it easier for Muslim tourists to fulfill their spiritual needs while traveling. The needs in this case, for example, are halal food, places of worship, and bathrooms that are separated for men and women (Azam et al., 2019; Vargas-Sanchéz and Perano, 2018).

Lombok's reputation as a halal tourist destination is very well known at international and regional levels, Lombok is indeed very suitable to be developed as halal tourism, besides Lombok has extraordinary natural beauty, the majority of Lombok's population is also Muslim, in Lombok, there are also very many mosques that even get predicate as the land of a thousand mosques.

The study will see whether Lombok deserves to be named the number 1 halal tourist destination in Indonesia according to the perspective of domestic Muslim tourists, by looking at how domestic Muslim tourists assess Lombok halal tourism, using the same indicators used by GMTI, including access, communication, environment and services which we later call the Tourism Index. This study is also an extension and adaptation of previous studies by Khoiriati et al. (2016) which highlights the branding and value of halal tourism in Lombok, Indonesia. In addition, Ainin et al. (2020) also discussed the concept and potential of halal tourism.

Why do we need to confirm the achievements that have been obtained by halal tourism in Lombok through the eyes of domestic Muslim tourists? There are several reasons that are important to do, including the recognition of domestic tourists on the conditions of halal tourism in Lombok which will further confirm or strengthen the results of the assessment of an award obtained from external parties. Then, the results of the assessment by domestic tourists will increase the confidence of domestic tourists about the actual conditions.

\section{LITERATURE REVIEW}

\section{Tourism index}

Tourism index or also known as travel image is a term that conditions the perception of tourists which includes aspects of service, taste, cleanliness, beauty, service facilities, and several other factors for an object during tourist activities (Suharto et al., 2019). Since the 2000s, various studies have discussed the factors that make geographical indicators the choice and destination of tourists in visiting. Apart from that, there are also several reasons for potential tourist attraction. In presenting it, Pablo-Romero et al. (2016), Dwyer and Kim (2003), Omerzel and

\footnotetext{
* Corresponding author
} 
Mihalic (2008), Crouch and Ritchie (1999), Croes and Kubickova (2013) and Darma et al. (2020) have focused on models that measure production through certain empirical methodologies, competitiveness, and tourism objectives. Thus, there are gaps and weaknesses in the general definition of the image of travel so that it becomes part of future studies. Universally, a definition that is accepted by all circles is not yet available. The definition must be sufficiently descriptive for understanding and adoption. From an individual and psychological point of view, the fact is that perception and image are highly correlated with travel. Perceptions of goal attributes and emotional viewpoints (feelings) about a tourist object can be the most sensible definitions from a future perspective (Mart1'n and Bosque, 2006; Madden et al., 2016; Whang et al., 2016).

\section{Experience quality}

There are two categories of service to quality cues related to functionality and emotional experience cues. Experience with products and results tends to the aspect of functionality. In fact, moments of truth and peace of mind are more dominant than experiences that tend to be associated with emotions. The quality of the customer experience must be measured through an affective (feeling) perspective because cognitive judgments are more significant on environmental stimuli and as primarily for the quality of the customer ex perience. The quality of the customer experience must measure the overall superiority of a brand emotionally after a cognitive assessment (Edvardsson, 2005; Rais et al., 2016). Evaluation of the quality of experience tends to be holistic or gestalt rather than at tribute-based, so that the focus in evaluation is aimed at self (internal), but not on the external service environment (Ratnasari et al., 2020).

The scope of experience is more general than specific regarding the nature of benefits as an experience and symbolic than its function and affective psychological representations are certainly not based on cognition or attitudes (Chen and Chen, 2010; Högström, 2011). Some researchers believe there is a two-way perspective on service quality and visitor satisfaction because they do not recognize the difference between quality performance and experience quality in tourism. The quality of the intended service attributes is under the control of the supplier, whereas the latter indicates not only the attributes provided by the supplier, but their attributes are also brought to chance by visitors in the recreational experience (Cole and Scott, 2004; Crompton and Love, 1995).

\section{Revisit intention}

The concept of intention to revisit comes from behavioral intention. Intentions include repurchase intentions and word-of-mouth is a situation where everything is connected from a behavioral point of view. In terms of tourism or recreation, the intention behaves as an intention to revisit the object within a certain time and the intention to come several times. Other factors involved in evaluating behavioral intention are through a desire to recommend to others and positive word of mouth. The intention of repeated visitors to a particular object can be influenced by the performance of the venue itself, for example by promotional efforts and news sprea ding about new attractions. Therefore, the intention to visit again can be interpreted as continuous satisfaction rather than the initiator of the decision-making process. This can be described as a strong likelihood of revisiting tourist attractions, whether or not with a positive attitude towards service providers (Oliver, 1997; Wu et al., 2015; Baker and Crompton, 2000; Bigné et al., 2005; Bintarti and Kurniawan, 2017; Aziz et al., 2012; Choo et al., 2016; Han et al., 2009; Um et al., 2006). In-depth, the intention to revisit tourist destinations is the willingness to visit repeatedly. Destination development is marketed to tourists so that they are interested in understanding and encouraging their intention to visit again. This becomes more efficient because the cost of retaining visitors is much low er than the cost of attracting new visitors at the same time (Seetanah et al., 2020; Soleimani and Einolahzadeh, 2018).

\section{METHODOLOGY}

\section{Conceptual framework and hypothesis}

A set of concepts and previous studies that can be developed in a logical and connected manner is a focus to form a theoretical framework. This is necessary so that this study can be sustained more measurably. The definitions and concepts that have been described previously, can provide a solid foundation, connect these concepts, and unify them through a logical connection with the study that is being carried out (Lara et al., 2020; McGregor, 2018; Grant and Osanloo, 2014). The following is the conceptual framework that we developed (Figure 1).

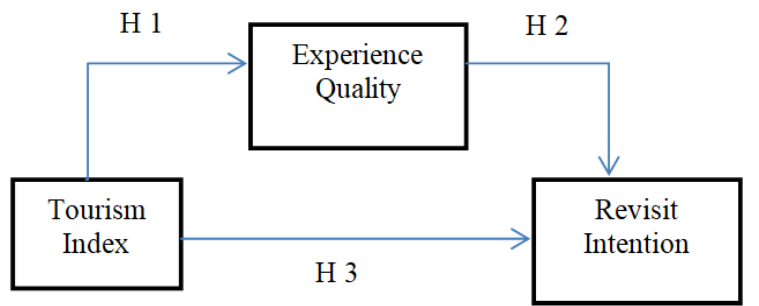

Figure 1. Variable design

Based on this conceptual framework, this study will prove the following hypotheses:

H1: There is a significant influence between tourism index and experience quality.

$\mathrm{H} 2$ : There is a significant influence between experience quality and revisit intention.

H3: There is a significant influence between tourism index and revisit intention.

\section{Measurement}

This study is included in the category of explanatory research, where the researcher tries to explain the influence of the three predetermined variables (Maria et al., 2019). The data is obtained from an online survey of domestic tourists who have visited all tourist objects in Lombok, provided that they are Indonesian citizenship and are Muslim, have visited a maximum of 24 months ago, are over 17 years old, and have at least stayed in Lombok.

\section{Sample}

Conditions that have been designed, so that respondents can answer all questions posed in the questionnaire. The questionnaire was arranged using an ordinal scale (1 to 10), provided that 1 strongly disagrees and 10 strongly agrees. The questionnaire needs to be tested for validity and reliability before using online surveys (Indriastuti et al., 2020). The survey was conducted from April to June 2020 which consisted of a number of participants who volunteered to fill out a questionnaire of 95 informants, but 87 of them met the criteria for respondents. Then, the data were 
processed using descriptive statistics and Partial Least Square (PLS). Descriptive statistics to explain demographics and respondent answers and this analysis model are suitable to be used to explain the relationship between the variables studied (Purwadi et al., 2020; Darma et al., 2020).

Table 1. Demographics (Data source: Distributed questionnaires)

\begin{tabular}{|c|c|c|c|}
\hline & \multirow[b]{2}{*}{ Category } & \multirow[b]{2}{*}{ Frequency } & \multirow[b]{2}{*}{$\%$} \\
\hline & & & \\
\hline \multirow{3}{*}{ Home town } & Jabodetabek & 11 & 12.6 \\
\hline & Non Jabodetabek & 76 & 87.4 \\
\hline & Total & 87 & 100.0 \\
\hline \multirow{5}{*}{ Educational background } & Diploma & 7 & 8.0 \\
\hline & Bachelor & 39 & 44.8 \\
\hline & Master & 23 & 26.4 \\
\hline & Doctoral & 18 & 20.7 \\
\hline & Total & 87 & 100.0 \\
\hline \multirow{6}{*}{ Age } & $17-25$ years & 4 & 4.6 \\
\hline & $26-35$ years & 20 & 23.0 \\
\hline & $36-45$ years & 26 & 29.9 \\
\hline & $46-55$ years & 24 & 27.6 \\
\hline & $>55$ years & 13 & 14.9 \\
\hline & Total & 87 & 100.0 \\
\hline \multirow{6}{*}{ The main job } & Government employees & 27 & 31.0 \\
\hline & Company employees & 28 & 32.2 \\
\hline & Entrepreneur & 22 & 25.3 \\
\hline & Student & 5 & 5.7 \\
\hline & Others & 5 & 5.7 \\
\hline & Total & 87 & 100.0 \\
\hline \multirow{6}{*}{ Spending } & < IDR 3.000.000 & 11 & 11.5 \\
\hline & IDR 3.000.000 - IDR 7.500.000 & 38 & 43.7 \\
\hline & IDR 7.500.0001 - IDR 15.000.000 & 22 & 25.3 \\
\hline & IDR 15.000.0001 - IDR 25.000.000 & 6 & 6.9 \\
\hline & > IDR 25.000 .000 & 10 & 11.5 \\
\hline & Total & 87 & 100.0 \\
\hline \multirow{6}{*}{ Last visit } & $<6$ months & 19 & 21.8 \\
\hline & $6-12$ months & 12 & 13.8 \\
\hline & 12-18 months & 10 & 11.5 \\
\hline & $18-24$ months & 15 & 17.2 \\
\hline & $>24$ months & 31 & 35.6 \\
\hline & Total & 87 & 100.0 \\
\hline \multirow{4}{*}{ Long time visiting } & $<3$ days & 11 & 12.6 \\
\hline & 3-7 days & 62 & 71.3 \\
\hline & $>7$ days & 14 & 16.1 \\
\hline & Total & 87 & 100.0 \\
\hline \multirow{5}{*}{ Number of visitors } & Self & 5 & 5.7 \\
\hline & 1-5 people & 53 & 60.9 \\
\hline & 6-10 people & 13 & 14.9 \\
\hline & $>10$ people & 16 & 18.4 \\
\hline & Total & 87 & 100.0 \\
\hline \multirow{6}{*}{ With whom } & Couple & 5 & 6.9 \\
\hline & Family & 28 & 32.2 \\
\hline & Friends / colleagues & 39 & 44.8 \\
\hline & Community & 10 & 11.5 \\
\hline & Alone & 5 & 4.6 \\
\hline & Total & 87 & 100.0 \\
\hline
\end{tabular}

Based on the 87 informants who were interviewed, they were divided into several classifications (home town, educational background, age, the main job, spending, last visits, long time visiting, number of visitors, and with whom). Table 1 also describes that most of the visitors came from outside Jabodetabek (Jakarta - Bogor - Depok - Tangerang - Bekasi) as many as 87.4\% with an undergraduate educational background reaching $44.8 \%$ and aged 36 - 45 years, namely $29.9 \%$. In addition, they are predominantly working as company workers by $32.2 \%$ and $43.7 \%$ of the tour costs that have been spent on tourist destinations in Lombok, on average, reaching IDR 3,000,000 - IDR $7,500,000$. As additional information, among these informants, the last visit was more than the last 24 months, namely $35.6 \%$ with an average visit time of $3-7$ days as much as $71.3 \%$. The largest number of visits in Lombok is in the range of $1-5$ people, $60.9 \%$ and $44.8 \%$ of them spend time on vacation there with friends (colleagues).

\section{Findings}

The assumption test carried out in this study aims to determine whether the data has met the assumptions so that further anal ysis can be carried out. The assumption tests carried out in this study are the missing data test, outlier test, and linearity test. The following are the results of the assumption tests that have been carried out. Data on the Experience Quality, Revisit Intention, and Tourism Index variables as many as 87 data have met the assumption of missing data because the data does not contain missing data or complete processed data, so Table 2 explains that this model can be continued to the next test.

Table 3 shows that the data used has a $\mathrm{z}$ score between \pm 4.00 , which means that the questionnaire unit of 87 tourist informants has fulfilled the outlier test assumption and there are no outlier data. Therefore, because it has met the data missing assumptions and outlier data, further testing can be carried out. Then, the data quality test used two stages, namely validity and reliability tests. Validity is a measure that shows the level of validity or validity of an instrument. Validity is a standard measure that shows the accuracy and validity of an instrument. An instrument is said to be valid if the instrument is able to measure what you want to measure (Latan et al., 2019). 
Table 2. Results of missing data assumptions Source: Result of PLS analysis

\begin{tabular}{|c|c|c|c|c|c|}
\hline \multirow[b]{2}{*}{ Indicators } & \multicolumn{2}{|c|}{$\mathbf{N}$} & \multirow[b]{2}{*}{ Indicators } & \multicolumn{2}{|c|}{$\mathbf{N}$} \\
\hline & Valid & Missing count & & Valid & Missing count \\
\hline EQ_1 & 87 & 0 & RI_1 & 87 & 0 \\
\hline EQ_2 & 87 & 0 & RI_2 & 87 & 0 \\
\hline EQ_3 & 87 & 0 & RI_3 & 87 & 0 \\
\hline EQ_4 & 87 & 0 & RI_4 & 87 & 0 \\
\hline EQ_5 & 87 & 0 & RI_5 & 87 & 0 \\
\hline EQ_6 & 87 & 0 & TI_1 & 87 & 0 \\
\hline EQ_7 & 87 & 0 & TI_2 & 87 & 0 \\
\hline EQ_8 & 87 & 0 & TI_3 & 87 & 0 \\
\hline EQ_9 & 87 & 0 & TI_4 & 87 & 0 \\
\hline EQ_10 & 87 & 0 & TI_5 & 87 & 0 \\
\hline EQ_11 & 87 & 0 & TI_6 & 87 & 0 \\
\hline EQ_12 & 87 & 0 & TI_7 & 87 & 0 \\
\hline EQ_13 & 87 & 0 & TI_8 & 87 & 0 \\
\hline EQ_14 & 87 & 0 & TI_9 & 87 & 0 \\
\hline EQ_15 & 87 & 0 & TI_10 & 87 & 0 \\
\hline EQ_16 & 87 & 0 & TI_11 & 87 & 0 \\
\hline EQ_17 & 87 & 0 & TI_12 & 87 & 0 \\
\hline EQ_18 & 87 & 0 & TI_13 & 87 & 0 \\
\hline EQ_19 & 87 & 0 & TI_14 & 87 & 0 \\
\hline EQ_20 & 87 & 0 & TI_15 & 87 & 0 \\
\hline EQ_21 & 87 & 0 & TI_16 & 87 & 0 \\
\hline EQ_22 & 87 & 0 & TI_17 & 87 & 0 \\
\hline EQ_23 & 87 & 0 & TI_18 & 87 & 0 \\
\hline EQ_24 & 87 & 0 & TI_19 & 87 & 0 \\
\hline EQ_25 & 87 & 0 & TI_20 & 87 & 0 \\
\hline EQ_26 & 87 & 0 & & & \\
\hline
\end{tabular}

Table 3. Outlier data Source: Result of PLS analysis

\begin{tabular}{|l|l|l|l|l|l|}
\hline Z Score & Min & Max & Z Score & Min & Max \\
\hline ZEQ_1 & -3.94226 & 1.16832 & ZRI_1 & -2.43853 & 1.03937 \\
\hline ZEQ_2 & -2.61879 & 1.30939 & ZRI_2 & -2.66517 & 1.13597 \\
\hline ZEQ_3 & -3.61645 & 1.24540 & ZRI_3 & -2.90081 & 1.09450 \\
\hline ZEQ_4 & -3.05551 & 1.20913 & ZRI_4 & -3.13602 & 1.06142 \\
\hline ZEQ_5 & -2.00136 & 1.23504 & ZRI_5 & -3.30307 & 1.17829 \\
\hline ZEQ_6 & -3.11547 & 1.31753 & ZTI_1 & -2.36389 & 1.78245 \\
\hline ZEQ_7 & -3.15879 & 1.22655 & ZTI_2 & -3.05982 & 1.38751 \\
\hline ZEQ_8 & -1.92961 & 1.51047 & ZTI_3 & -3.22324 & 1.61162 \\
\hline ZEQ_9 & -2.06955 & 1.40633 & ZTI_4 & -3.43804 & 1.46539 \\
\hline ZEQ_10 & -3.60523 & 1.34722 & ZTI_5 & -3.02247 & 1.39164 \\
\hline ZEQ_11 & -2.53689 & 1.39032 & ZTI_6 & -3.43462 & 1.45249 \\
\hline ZEQ_12 & -1.96208 & 1.55029 & ZTI_7 & -2.76526 & 1.62027 \\
\hline ZEQ_13 & -2.34474 & 1.46109 & ZTI_8 & -2.52468 & 1.65339 \\
\hline ZEQ_14 & -2.60170 & 1.39738 & ZTI_9 & -3.18486 & 1.28422 \\
\hline ZEQ_15 & -2.29874 & 1.43242 & ZTI_10 & -3.31587 & 1.26319 \\
\hline ZEQ_16 & -3.10386 & 1.31089 & ZTI_11 & -3.04273 & 1.23842 \\
\hline ZEQ_17 & -2.69727 & 1.05733 & ZTI_12 & -2.42212 & 1.36789 \\
\hline ZEQ_18 & -2.51816 & 1.28531 & ZTI_13 & -2.91737 & 1.49674 \\
\hline ZEQ_19 & -3.48593 & 1.24352 & ZTI_14 & -2.54068 & 1.44920 \\
\hline ZEQ_20 & -2.55557 & 1.40683 & ZTI_15 & -3.87190 & 1.26113 \\
\hline ZEQ_21 & -3.64651 & 1.38028 & ZTI_16 & -2.85049 & 1.16234 \\
\hline ZEQ_22 & -3.78718 & 1.66385 & ZTI_17 & -2.71073 & 1.48809 \\
\hline ZEQ_23 & -2.99371 & 1.53590 & ZTI_18 & -2.97337 & 1.14579 \\
\hline ZEQ_24 & -2.20770 & 1.55838 & ZTI_19 & -2.65085 & 1.25803 \\
\hline ZEQ_25 & -2.81655 & 1.62718 & ZTI_20 & -2.75193 & 1.51251 \\
\hline ZEQ_26 & -3.05699 & 1.57412 & & & \\
\hline
\end{tabular}

Validity as an aspect of measurement accuracy. A valid measuring instrument is not only able to produce the right data but al so must provide an accurate picture of the data. Meanwhile, reliability is the extent to which measurement results using the same object will produce the same data (Pamungkas et al., 2018). Table 4 shows the results of the validity test carried out by measuring discriminant validity by looking at the cross-loading value of the research data. The data can be said to be valid if the indicator has the greatest cross-loading value when paired with the dimensions of its partner compared to other dimensions in the measurement, so from this value. it will be seen the ability of the indicators in the questionnaire questions to reflect their respective dimensions and variables (Hiong et al., 2020).

The next stage is to test the reliability to determine the level of consistency of each indicator in measuring the construct variables. This test can be done by calculating the value of Cronbach's alpha and composite reliability. Composite reliability ( $\rho$ ) with a cut-off value of more than $70 \%$, then the indicator group is said to be good. Meanwhile, the indicator is said to be reliable when Cronbach's alpha is above $60 \%$ (Lau et al., 2019). All indicators have been proven reliable in measuring the latent variables. This can be seen from the value of the variables and dimensions having Cronbach's alpha value and the composite reliability value above the provisions. After that, the test also determines the significance of the relationship between the variables and their dimensions. This needs to be done considering that the research model uses the second-order model (Table 5). The outer model path coefficient in Table 6 explains that the tourism index has an influence on experience quality and experience quality also has an influence on revisit intention. On the one hand, the tourism index has no influence on revisit intention. The acquisition of $\mathrm{R}$-square shows the strong or weak influence of the independent variables on the dependent variable. Table 7 shows that the tourism index has a weak effect on experience quality, experience quality has a moderate effect on revisit intention, and tourism index has no effect on revisit intention. The F-square achievement shows the size of the relationship between the independent variables and the dependent variable. This test shows that the tourism index has a small relationship with experience quality, experience quality has a large relationship with revisit intention, and tourism index has no relationship with revisit intention (Table 8). 


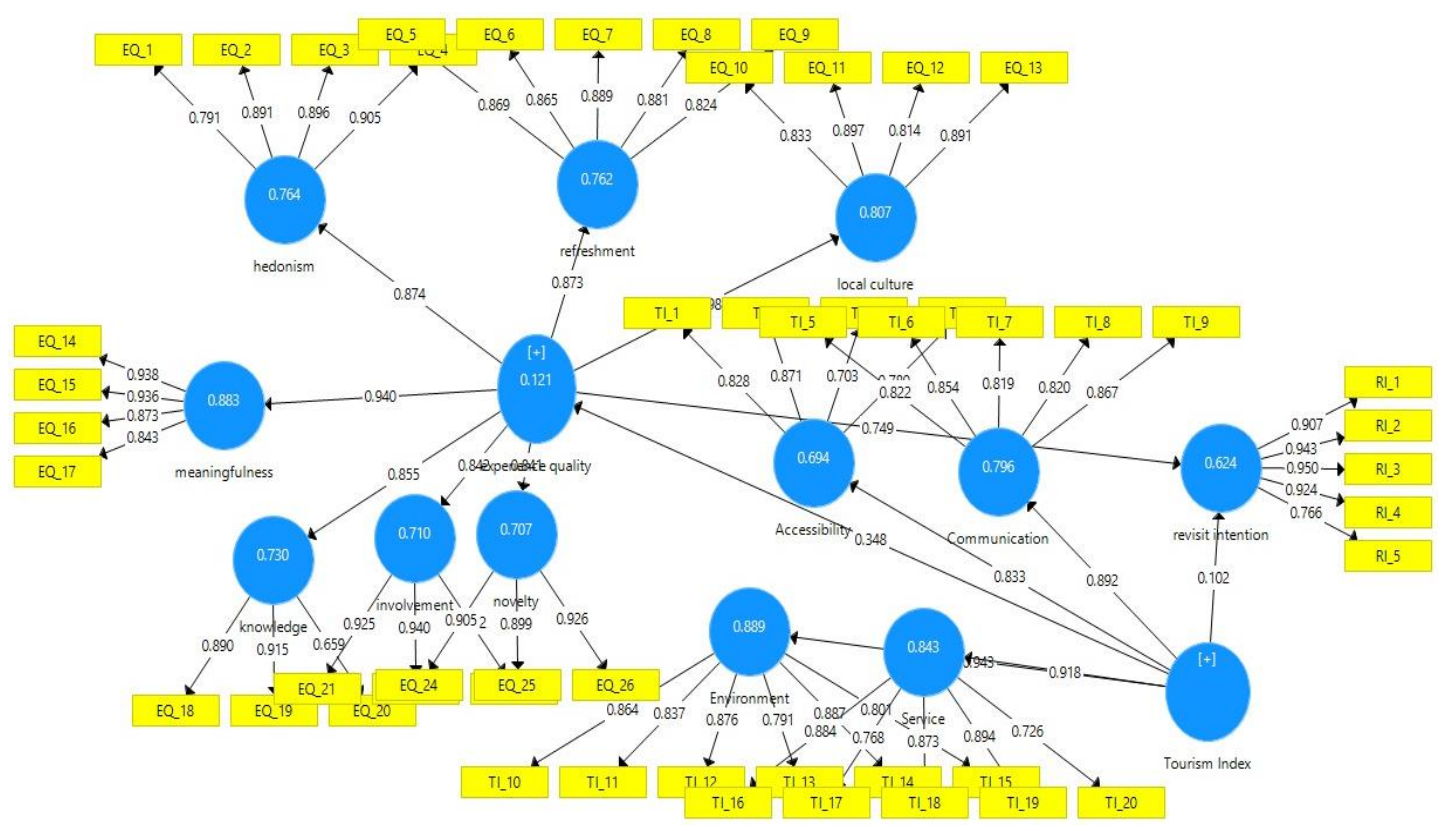

Figure 2. PLS algorithm

Table 4. Convergent validity test Source: Result of PLS analysis

\begin{tabular}{|c|c|c|c|c|c|}
\hline \multirow{2}{*}{ Variables } & \multirow{2}{*}{ Dimensions } & \multirow{2}{*}{ Indicators } & \multirow{2}{*}{ Outer loading } & \multicolumn{2}{|c|}{ AVE } \\
\hline & & & & Dimensions & Variables \\
\hline \multirow{20}{*}{$\begin{array}{l}\text { Tourism } \\
\text { Index }\end{array}$} & \multirow{4}{*}{ Accessibility } & T1 & .828 & \multirow{4}{*}{.637} & \multirow{20}{*}{.562} \\
\hline & & $\mathrm{T} 2$ & .871 & & \\
\hline & & T3 & .730 & & \\
\hline & & T4 & .780 & & \\
\hline & \multirow{5}{*}{ Communication } & T5 & .822 & \multirow{5}{*}{.700} & \\
\hline & & T6 & 854 & & \\
\hline & & $\mathrm{T} 7$ & .819 & & \\
\hline & & T8 & .820 & & \\
\hline & & T9 & .867 & & \\
\hline & \multirow{6}{*}{ Environment } & T1 & .864 & \multirow{6}{*}{.712} & \\
\hline & & $\mathrm{T} 11$ & .837 & & \\
\hline & & T12 & 876 & & \\
\hline & & T13 & .791 & & \\
\hline & & T14 & .887 & & \\
\hline & & T15 & .810 & & \\
\hline & \multirow{5}{*}{ Service } & T16 & .884 & \multirow{5}{*}{.692} & \\
\hline & & T17 & .767 & & \\
\hline & & T18 & .873 & & \\
\hline & & T19 & .894 & & \\
\hline & & $\mathrm{T} 2$ & .726 & & \\
\hline \multirow{24}{*}{$\begin{array}{l}\text { Experience } \\
\text { Quality }\end{array}$} & \multirow{4}{*}{ Hedonism } & EQ1 & .791 & \multirow{4}{*}{.761} & \multirow{24}{*}{.594} \\
\hline & & EQ2 & .891 & & \\
\hline & & EQ3 & .896 & & \\
\hline & & EQ4 & 950 & & \\
\hline & \multirow{5}{*}{ Refreshment } & EQ5 & 869 & \multirow{5}{*}{.750} & \\
\hline & & EQ6 & .865 & & \\
\hline & & EQ7 & .889 & & \\
\hline & & EQ8 & .881 & & \\
\hline & & EQ9 & .824 & & \\
\hline & & EQ1 & .833 & & \\
\hline & & EQ11 & 897 & & \\
\hline & Local Culture & EQ12 & .814 & .738 & \\
\hline & & EQ13 & .891 & & \\
\hline & & EQ14 & .938 & & \\
\hline & Meanıngfulness & EQ15 & 936 & .870 & \\
\hline & & EQ18 & 890 & & \\
\hline & Knowledge & EQ19 & 915 & .688 & \\
\hline & & EQ2 & .659 & & \\
\hline & & EQ21 & 925 & & \\
\hline & Involvement & EQ22 & .940 & .844 & \\
\hline & & EQ23 & .892 & & \\
\hline & & EQ24 & .950 & & \\
\hline & Novelty & EQ25 & 899 & .828 & \\
\hline & & EQ26 & .926 & & \\
\hline & & RI1 & 970 & & \\
\hline & & RI2 & .943 & & \\
\hline $\begin{array}{l}\text { Revisit } \\
\text { Intention }\end{array}$ & & RI3 & .950 & .811 & .811 \\
\hline Intention & & RI4 & .924 & & \\
\hline & & RI5 & .766 & & \\
\hline
\end{tabular}


Figure 2 illustrates the study model is a reflexive indicator (principal factor model), where the covariance of the indicator measurement is influenced by the latent construct or reflects the variation of the latent construct. This model is able to ex plain that each indicator is a measurement of the error imposed on latent variables.

The direction of cause and effect is from the latent variable to the indicator because these indicators are a reflection of the variation of the latent variable (Henseler et al., 2009). This means that changes in latent variables can cause an increase in all of its indicators.

Table 5. Test composite reliability Source: Result of PLS analysis

\begin{tabular}{|l|c|c|}
\hline \multicolumn{1}{|c|}{ Variables and dimensions } & Cronbach's Alpha & CR \\
\hline Tourism Index & .958 & .962 \\
\hline Accessibility & .880 & .875 \\
\hline Communication & .893 & .921 \\
\hline Environment & .919 & .937 \\
\hline Service & .887 & .918 \\
\hline Experience Quality & .972 & .974 \\
\hline Hedonism & .894 & .927 \\
\hline Involvement & .980 & .942 \\
\hline Knowledge & .769 & .866 \\
\hline Local Culture & .881 & .919 \\
\hline Meaningfulness & .920 & .943 \\
\hline Novelty & .896 & .935 \\
\hline Refreshment & .917 & .937 \\
\hline Revisit Intention & .940 & .955 \\
\hline
\end{tabular}

Table 6. Path coefficient Source: Result of PLS analysis

\begin{tabular}{|l|c|c|}
\hline \multicolumn{1}{|c|}{ Relationships } & T values & P values \\
\hline Tourism Index -> Experience Quality & 3.059 & .002 \\
\hline Tourism Index -> Revisit Intention & 1.607 & .109 \\
\hline Experience Quality -> Revisit Intention & 14.204 & .000 \\
\hline
\end{tabular}

Table 7. R-square test Source: Result of PLS analysis

\begin{tabular}{|l|c|c|}
\hline \multicolumn{1}{|c|}{ Relationships } & R-square & Effect \\
\hline Tourism Index $->$ Experience Quality & .121 & Weak \\
\hline Tourism Index $\rightarrow$ Revisit Intention & .000 & Nothing \\
\hline Experience Quality -> Revisit Intention & .624 & Moderat \\
\hline
\end{tabular}

Table 8. F-square test Source: Result of PLS analysis

\begin{tabular}{|l|c|c|}
\hline \multicolumn{1}{|c|}{ Models } & Effect Size & Remarks \\
\hline Tourism Index - Experience Quality & 0.138 & Small \\
\hline Experience Quality - Revisit Intention & 1.311 & Big \\
\hline Tourism Index - Revisit Intention & .000 & Nothing \\
\hline
\end{tabular}

The Q-square test was conducted to determine the ability of the model to predict the relationship between variables presented in the study. Based on Table 7, the Q-square value can be calculated with the following formula:

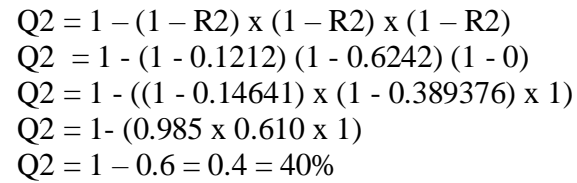

From these calculations, it can be seen that the Q-square value indicates that the magnitude of the diversity of the studies that can be explained by the structural model is $40 \%$. This means that the representation of the structural model is able to map $40 \%$ of the actual conditions and there is a factor of $60 \%$ outside the model used and still needs to be explored again. It can be seen that the structural model of this study has good predictive relevance because the Q-Square value shown has exceeded the value of 0.35 .

Assessment of goodness of fit needs to be done to see the goodness of the model through consideration of the AVE value score and also the R-Square value by doing calculations. The criteria for the GoF small (0.1), GoF medium (0.25), and GoF large (0.38). The GoF acquisition reached 0.685 which is classified as strong because it has a score of more than 0.38 (the fit model is good). Ale xopoulos (2010) and Guillera-Arroita (2016) highlighted the difference with CBSEM, for the goodness of fit value on PLS-SEM must be searched manually. Schermelleh-Engel et al. (2003) also added that the criteria for the GoF small (0.1), GoF medium (0.25), and GoF large (0.38). The GoF acquisition reached 0.685 which is classified as strong because it has a score of more than 0.38 (the fit model is good).

$$
G O F=\sqrt{\overline{A V E} \times \overline{R^{2}}}=\sqrt{0,655 \times 0,717}=\sqrt{0,469635}=0,685
$$

Table 9 highlights the hypothesis that the tourism index has a significant effect on experience quality (accepted), experience quality has a significant effect on revisit interest (accepted), and tourism index has a significant effect on revisit intention (rejected).

Table 9. Probability Source: Result of PLS analysis

\begin{tabular}{|l|c|c|c|c|}
\hline \multicolumn{1}{|c|}{ Relationships } & Path & T statistics & P values & Hypothesis \\
\hline Tourism Index $\rightarrow$ Experience Quality & .348 & 3.059 & .002 & Accepted \\
\hline Tourism Index $\rightarrow$ Revisit Intention & .102 & 1.607 & .109 & Rejected \\
\hline Experience Quality $\rightarrow$ Revisit Intention & .749 & 14.204 & .000 & Accepted \\
\hline
\end{tabular}




\section{DISCUSSIONS}

Indonesia as a country where the majority of its people embrace Islam, the trend of halal tourism is still not very popular, and still has pros and cons in society. This is because the Indonesian people still have a narrow understanding of the concept of halal tourism. The perception that develops in the community is that when a tourist area is developed with the concept of halal tourism, the tourist area only prioritizes Muslim tourists and subordinates tourists to other religions (Triyawan and Carolina, 2018; Hakim et al., 2017). Indonesia is predominantly Muslim, so the attributes required for halal tourism are less important, for example, halal labels, non-halal labels of food sold in shops, and halal labels for food in restaurants. In fact, this is also very important to increase the sense of security and comfort of tourists during tourist visits (Battour et al., 2018). Halal tourism is a tourism concept that has the potential to continue to be developed considering the very rapid growth of Islam. In addition, spending by Muslim tourists is estimated to reach US\$ 2 billion by 2020. Now many countries in the world such as Hong Kong and Singapore are competing to improve and improve their tourist facilities so that they can be friendly to Muslim tourists (Rusli et al., 2019; Peristiwo, 2020). Indonesia also does not want to be outdone, since 2019 together with Malaysia, Indonesia has occupied the first position as the most popular halal tourist destination based on the Global Muslim Travel Index (GMTI). Lombok is Indonesia's mainstay halal tourist destination. Lombok in 2015 received an award as the world's best halal tourist destination from The World Halal Travel Summit and Exhibition (2019) and was ranked 1 in the "Indonesian Muslim Travel Index" (Subarkah et al., 2020).

In the Lombok region, there are various types of tourism that have become a mainstay during the last few periods, including beaches, mountains, hills, parks, local hamlets, small islands, and waterfalls. These tourist destinations include Kuta Beach, Selong Belanak Beach, Tanjung Aan Beach, Bangko-Bangko Beach, Tangsi Beach, Mount Rinjani, Pergasingan Hill, Namada Park, Sade Hamlet, Senggigi Beach, Gili Trawangan, Gili Air, Gili Meno, Gili Nanggu, Gili Layar, Tiu Kelep Waterfall, and Sendang Gile Waterfall. The fifteen objects are still being developed, especially in terms of providing facilities and infrastructure to support halal tourism activities (Maulidi, 2019; Taqwiem et al., 2020).

\section{CONCLUSIONS AND SUGGESTIONS}

Referring to the empirical findings, we conclude that the first hypothesis and the second hypothesis are acceptable, while the third hypothesis has been rejected. The results reveal if the season index has a significant effect on experience quality and experience quality has a significant effect on revisit intention. However, the tourism index did not have a significant effect on revisit intention.

These results are in line with and supported by several previous studies that explain the relationship between season index, experience quality, and revisit intention in different tourist destinations in several countries (Ramdhani and Astuti, 2019; Nguyen, 2020; Purnama and Wardi, 2019; Viet et al., 2020; Lin et al., 2018). This study has limitations on the number of samples, the survey period, and the variables used so that future researchers are expected to consider these three things so that the discussion is more varied. For the government, academics, and tourism destination managers, they can work together in determining the right program to increase the dimensions and indicators related to this variable model. A good policy certainly refers to the perception of positive suggestions from tourists, so that tourism potential in Lombok can be optimized in a sustainable manner.

\section{Conflict of interest}

We declare no conflicts of interest at a later date and this study is aimed at various parties.

\section{REFERENCES}

Ainin, S., Feizollah, A., Anuar, N.B., \& Abdullah, N.A. (2020). Sentiment analyses of multilingual tweets on halal tourism. Tourism Management Perspectives, 34, 100658. https://doi.org/10.1016/j.tmp.2020.100658

Alexopoulos, E.C. (2010). Introduction to multivariate regression analysis. Hippokratia, 14(Suppl 1), $23-28$.

Azam, M.S., Abdullah, M.A., \& Razak, D.A. (2019). Halal tourism: Definition, justification, and scopes towards sustainable development. International Journal of Business, Economics and Law, 18(3), 23-31.

Aziz, N.A., Ariffin, A.A., Osmar, N.A., \& Evin, C. (2012). Examining the impact of visitors' emotions and perceived quality towards satisfaction and revisit intention to theme parks. Jurnal Pengurusan, 35, 97-109.

Baker, D.A., \& Crompton, J.L. (2000). Quality, satisfaction and behavioral intentions. Annals ofmTourism Research, 27(3), 785-804. https://doi.org/10.1016/S0160-7383(99)00108-5

Battour, M., \& Ismail, N. (2016). Halal tourism: Concepts, practises, challenges and future. Tourism Management Perspectives, 19(B), 150-154. https://doi.org/10.1016/j.tmp.2015.12.008

Battour, M., Hakimian, F., Ismail, M., \& Boğan, E. (2018). The perception of non-Muslim tourists towards halal tourism: Evidence from Turkey and Malaysia. Journal of Islamic Marketing, 9(4), 823-840. https://doi.org/10.1108/JIMA-07-2017-0072

Bigné, J.E., Andreu, L., \& Gnoth, J. (2005). The theme park experience: An analysis of pleasure, arousal and satisfaction. Tourism Management, 26(6), 833844. https://doi.org/10.1016/j.tourman.2004.05.006

Bintarti, S., \& Kurniawan, E.N. (2017). A Study of Revisit Intention: Experiential Quality and Image of Muara Beting Tourism Site in Bekasi District. European Research Studies Journal, 20(2), 521-537.

Chen, C.F., \& Chen, F.S. (2010). Experience quality, perceived value, satisfaction and behavioral intentions for heritage tourists. Tourism Management, 31 , 29-35. https://doi.org/10.1016/j.tourman.2009.02.008

Choo, H., Ahn, K., \& Petrick, J. (2016). An integrated model of festival revisit intentions: Theory of planned behavior and festival quality/satisfaction. International Journal of Contemporary Hospitality Management, 28(4), 818-838. https://doi.org/10.1108/IJCHM-09-2014-0448

Cole, S.T., \& Scott, D. (2004). Examining the Mediating Role of Experience Quality in a Model of Tourist Experiences. Journal of Travel \& Tourism Marketing, 16(1), 79-90. https://doi.org/10.1300/j073v16n01_08

Croes, R., \& Kubickova, M. (2013). From potential to ability to compete: towards a performance-based tourism competitiveness index. Journal of Destination Marketing and Management, 2(3), 146-154. https://doi.org/10.1016/j.jdmm.2013.07.002

Crompton, J.L., \& Love, L.L. (1995). The Predictive Validity of Alternative Approaches to Evaluating Quality of a Festival. Journal of Travel Research, 34(1), 11-24. https://doi.org/10.1177/004728759503400102

Crouch, G.I., \& Ritchie, J.B. (1999). Tourism, competitiveness, and societal prosperity. Journal of Business Research, 44(3), 137-152. https://doi.org/10.1016/S0148-2963(97)00196-3

Darma, D.C., Purwadi, P., Sundari, I., Hakim, Y.P., \& Pusriadi, T. (2020). Job Characteristics, Individual Characteristics, Affective Commitments and Employee Performance. Research and Review: Human Resource and Labour Management, 1(1), 7-18. https://doi.org/10.5281/zenodo.3719117

Darma, D.C., Maria, S., Kasuma, J., \& Lestari, D. (2020). Factors involved in the number of tourist visits in the Muara Badak, Indonesia. Religación. Revista De Ciencias Sociales Y Humanidades, 5(24), 142-151. https://doi.org/10.46652/rgn.v5i24.623

Dwyer, L., \& Kim, C. (2003). Destination competitiveness: Determinants and indicators. Current Issues in Tourism, 6(5), 369-414. https://doi.org/10.1080/13683500308667962

Edvardsson, B. (2005). Service quality: Beyond cognitive assessment. Managing Service Quality: An International Journal, 15(2), 127-131. https://doi.org/10.1108/09604520510585316

Grant, C., \& Osanloo, A. (2014). Understanding, Selecting, and Integrating a Theoretical Framework in Dissertation Research: Creating the Blueprint for Your "House". Administrative Issues Journal: Connecting Education, Practice, and Research, 4(2), 12-26. https://doi.org/10.5929/2014.4.2.9

Guillera-Arroita, G. (2016). Modelling of species distributions, range dynamics and communities under imperfect detection: advances, challenges and opportunities. Ecography, 40, 281-295. https://doi.org/10.1111/ecog.02445 
Hakim, A.A., Ridwan, H., Hasanuddin, \& Al-Hakim, S. (2017). Towards Indonesia Halal Tourism. Ahkam, 17(2), 279-300. https://doi.org/10.15408/AJIS.V17I2.6243

Han, H., Back, K.J., \& Barrett, B. (2009). Influencing factors on restaurant customers' revisit intention: The roles of emotions and switching barriers. International Journal of Hospitality Management, 28(4), 563-572. https://doi.org/10.1016/j.ijhm.2009.03.005

Henseler, J., Ringle, C. M., \& Sinkovics, R. R. (2009). The use of partial least squares path modeling in international marketing. Advances in International Marketing, 20, 277-319. https://doi.org/10.1108/S1474-7979(2009)0000020014

Hiong, L.S., Ferdinand, A.T., \& Listiana, E. (2020). Techno-resonance innovation capability for enhancing marketing performance: a perspective of RAtheory. Verslas: Teorija ir praktika, 21(1), 329-339. https://doi.org/10.3846/btp.2020.12117

Högström, C. (2011). The theory of attractive quality and experience offerings. The TQM Journal, 23(2), 111-127. https://doi.org/10.1108/17542731111110195

Indriastuti, H., Kasuma, J., Zainurrosalamia, S., Darma, D.C., \& Sawangchai, A. (2020). Achieving Marketing Performance through Acculturative Product Advantages: The Case of Sarong Samarinda. Asian Journal of Business and Accounting, 13(1), 241-261. https://doi.org/10.22452/ajba.vol13no1.9

Khoiriati, S.D., Suharoko, S., Krisnajaya, I.M., \& Dinarto, D. (2018). Debating Halal Tourism Between Values and Branding: A Case Study of Lombok, Indonesia. KnE Social Sciences, 3(5), 494-515. https://doi.org/10.18502/kss.v3i5.2352

Khoiriati, H., Chiappetta Jabbour, C.J., \& Lopes de Sousa Jabbour, A.B. (2019). 'Whistleblowing triangle': Framework and empirical evidence. Journal of Business Ethics, 160(1), 189-204. https://doi.org/10.1007/s10551-018-3862-x

Latan, H., Jabbour, C. J., \& Jabbour, A. B. (2019). Whistleblowing Triangle': Framework and Empirical Evidence. Journal of Business Ethics, 160, 189-204 https://doi.org/10.1007/s10551-018-3862-x

Lara, V., Elise, P., Sebastian, U., \& Meredith, Y. (2020). The Distinctions Between Theory, Theoretical Framework, and Conceptual Framework. Academic Medicine, 95(7), 989-994. https://doi.org/10.1097/ACM.0000000000003075

Lau, E., Hamzah, S.N., \& Habibullah, M.S. (2019). The Economic of Deterrence: A Wrong Policy or A Misplaced Strategy?. Jurnal Ekonomi Malaysia, 53(1), 105-119. http://dx.doi.org/10.17576/JEM-2019-5301-9

Lin, Y.C., Lee, Y.H., Su, J.M., \& Hsieh, L.Y. (2018). Relationships among service quality, experiential marketing, and the revisit intention of visitors to tourism factories. International Journal of Economics and Research, 9(2), 22-37.

Maria, S., Darma, D.C., Amalia, S., Hakim, Y.P., \& Pusriadi, T. (2019). Readiness to face industry 4.0. International Journal of Scientific and Technology Research, 8(9), 2363-2368.

Martı'n, H.S. \& Bosque, I.A. (2006). Exploring the cognitive-affective nature of destination image and the role of psychological factors in its formation. Tourism Management, 29, 263-277. https://doi.org/10.1016/j.tourman.2007.03.012

Madden, K., Rashid, B., \& Zaino, N.A. (2016). Beyond the motivation theory of destination image. Tourism and Hospitality Management, $22(2), 247-264$. https://doi.org/10.20867/thm.22.2.1

Maulidi, M.J. (2019). Wisata Halal dan Identitas Islami: Studi Kasus Lombok, Nusa Tenggara Barat. Jurnal Pemikiran Sosiologi, 6(1), 18-26. https://doi.org/10.22146/jps.v6i1.47464

McGregor, S. (2018). Conceptual frameworks, theories, and models. McGregor, S. Understanding and evaluating research, 51-91, Thousand Oaks, CA: SAGE Publications. https://doi.org/10.4135/9781071802656

Nguyen, X.T. (2020). Factors That Influence the Intentions to Revisit Korea of Vietnamese Tourists. Journal of Asian Finance, Economics and Business, 7(4), 247-258. https://doi.org/10.13106/jafeb.2020.vol7.no4.247

Oliver, R.L. (1997). Satisfaction A Behavioral Perspective On The Consumer. McGraw-Hill Education, Singapore.

Omerzel, D.G., \& Mihalic, T. (2008). Destination Competitiveness-Applying Different Models, the Case of Slovenia. Tourism Management, 29(2), 294-307. https://doi.org/10.1016/j.tourman.2007.03.009

Pablo-Romero, M.P., Gómez-Calero, P., \& Sánchez-Rivas, J. (2016). Tourism, Competitiveness and Economic Growth: A New Analytical Model. Tourism From Empirical Research Towards Practical Application, 6, 112-135. https://doi.org/10.5772/62276

Pamungkas, I.D., Ghozali, I., Achmad, T., Khaddafi, M., \& Hidayah, R. (2018). Corporate Governance Mechanisms in Preventing Accounting Fraud: A Study of Fraud Pentagon Model. Journal of Applied Economic Sciences Quarterly, 8(2), 549-560.

Peristiwo, H. (2020). Indonesian and Malaysian potential for a Halal Tourism Industry. African Journal of Hospitality, Tourism and Leisure, 9(1), 1-16.

Purnama, W., \& Wardi, Y. (2019). The Influence of Destination Image, Tourists Satisfaction, and Tourists Experience toward Revisit Intention to The Most Beautiful Village in The World (Nagari Tuo Pariangan). Jurnal Kajian Manajemen dan Wirausaha, 1(1), 18-25. http://dx.doi.org/10.24036/jkmw0260270

Purwadi, P., Darma, D.C., Febrianti, W., \& Mirwansyah, D. (2020). Exploration of Leadership, Organizational Culture, Job Satisfaction, and Employee Performance. Technium Social Sciences Journal, 6(1), 116-130. https://doi.org/10.47577/tssj.v6i1.242

Rais, N.M., Musa, R., \& Muda, M. (2016). Reconceptualisation of Customer Experience Quality (CXQ) Measurement Scale. Procedia Economics and Finance, 37, 299-303. https://doi.org/10.1016/S2212-5671(16)30128-9

Ramdhani, A., \& Astuti, S. (2019). The analysis of relationship between experiential marketing, service quality, visitors' satisfaction, and revisit intention: Study on tourism industry. Diponegoro International Journal of Business, 2(2), 107-111. https://doi.org/10.14710/dijb.2.2.2019.107-111

Ratnasari, S. L., Susanti, E. N., Ismanto, W., Tanjung, R., Darma, D. C., \& Sutjahjo, G. (2020). An Experience of Tourism Development: How is the Strategy?. Journal of Environmental Management \& Tourism, 11(7), 1877-1886. http://dx.doi.org/10.14505//jemt.v11.7(47).26

Rusli, M., Firmansyah, R., \& Mbulu, Y.P. (2019). Halal Tourism Destination Development Model. Journal of Environmental Management and Tourism, 9(6), 1296-1302. http://dx.doi.org/10.14505//jemt.9.6(30).19

Satriana, E.D., \& Faridah, H.D. (2018). Halal tourism: Development, chance and challenge. Journal of Halal Product and Research, 1(2), 32-43. http://dx.doi.org/10.20473/jhpr.vol.1-issue.2.32-43

Schermelleh-Engel, K., Moosbrugger, H., \& Müller, H. (2003). Evaluating the Fit of Structural Equation Models: Tests of Significance and Descriptive Goodness-of-Fit Measures. Methods of Psychological Research, 8(2), 23-74.

Seetanah, B., Teeroovengadum, V., \& Nunkoo, R. (2020). Destination Satisfaction and Revisit Intention of Tourists: Does the Quality of Airport Services Matter?. Journal of Hospitality \& Tourism Research, 44(1), 134-148. https://doi.org/10.1177/1096348018798446

Soleimani, A.G., \& Einolahzadeh, H. (2018). The influence of service quality on revisit intention: The mediating role of WOM and satisfaction (Case study: Guilan travel agencies). Cogent Social Sciences, 4(1), 1560651. https://doi.org/10.1080/23311886.2018.1560651

Subarkah, A.R., Rachman, J.B., \& Akim, A. (2020). Destination Branding Indonesia sebagai Destinasi Wisata Halal. Jurnal Kepariwisataan: Destinasi, Hospitalitas dan Perjalanan, 4(2), 84-97. http://dx.doi.org/10.34013/jk.v4i2.53

Suharto, R.B., Roy, J., \& Darma, D.C. (2019). Degree of potential and development strategy of tourism objects. International Journal of Scientific and Technology Research, 8(9), 2343-2347.

Suradin, M. (2018). Halal Tourism Promotion in Indonesia: An Analysis on Official Destination Websites. Journal of Indonesian Tourism and Development Studies, 6(3), 143-158. https://doi.org/10.21776/ub.jitode.2018.006.03.01

Taqwiem, A., Al Rasyid Muhammad, H., \& Maulidi, A. (2020). Halal Tourism Development Analysis in Lombok Island. KnE Social Sciences, 4(9), 177-184. https://doi.org/10.18502/kss.v4i9.7324

Triyawan, A., \& Carolina, R. (2018). Analysis of halal tourism development strategy in East Java Province. Journal of Islamic Economics Lariba, 4(1), 27-35. https://doi.org/10.20885/jielariba.vol4.iss1.art3

Um, S., Chon, K., \& Ro, Y.H. (2006). Antecedents of revisit intention. Annals of Tourism Research, 33(4), 1141-1158. https://doi.org/10.1016/j.annals.2006.06.003

Vargas-Sanchéz, A., \& Perano, M. (2018). Halal Tourism through the Lens of Generation Z in a Muslim Majority Country: Implications on Tourist Services International Journal of Business and Management, 13(9), 36-49. https://doi.org/10.5539/ijbm.v13n9p36

Viet, B.N., Dang, H.P., \& Nguyen, H.H. (2020). Revisit intention and satisfaction: The role of destination image, perceived risk, and cultural contact. Cogent Business \& Management, 7, 1796249. https://doi.org/10.1080/23311975.2020.1796249

Whang, H., Yong, S., \& Ko, E. (2016). Pop culture, destination images, and visit intentions: Theory and research on travel motivations of Chinese and Russian tourists. Journal of Business Research, 69(2), 631-641. https://doi.org/10.1016/j.jbusres.2015.06.020

Wu, H.C., Ai, C.H., Yang, L.J., \& Li, T. (2015). A Study of Revisit Intentions, Customer Satisfaction, Corporate Image, Emotions and Service Quality in the Hot Spring Industry. Journal of China Tourism Research, 11(4), 371-401. https://doi.org/10.1080/19388160.2015.1110545

*** The World Halal Travel Summit. (2019). Halal Tourism- An Overview, The World Halal Travel Summit and Exhibition 2019. Retrieved from https://tcaabudhabi.ae/en/events/our.events/halal.tourism.aspx [September 21, 2020]. 